\title{
The application of event tree analysis in a work accident at maintenance operations
}

\author{
Radu Mareş⿻ ${ }^{1, *}$, and Mihai Popescu - Stelea ${ }^{1}$ \\ ${ }^{1}$ University of Petroşani, 20 Universităţii st., Petroşani 332006, Romania
}

\begin{abstract}
Event tree analysis is an inductive method, which involves determining the events flowing from the failure of a component or part of the system. Starting from an initiator event or an origin failure, the event tree analysis allows the estimation of system deviation, taking into account in a systematic manner the functioning or failure of detection devices, alarm, prevention, protection or intervention. This paper follows the steps in determining the causes that led to a work accident through the Event Tree Analysis method. The construction of event tree analysis consists of graphical representation of operations which through a succession of decisions lead to an accident during maintenance of work equipment.
\end{abstract}

\section{Introduction}

For understanding any risk is necessary to know its structure and its mode of expression [1, 4-5]. It must therefore be addressed complexity and all its required knowledge fields. Extensive efforts are needed since life is a continuous risk and there can be progress to increase our comfort without taking some risks.

This progress involves becoming more a rejection of imposed risks resulting from human activities conducted within work processes. But there are risks which are not imposed (related to road traffic, from domestic activities or the leisure) which shall neither they disregard [1].

\section{Theoretical fundamentals}

Event tree analysis is a method that allows determining, from an initiating event, the chaining of events that may lead to a potential accident $[2,4]$.

The method finds particular applicability to study architecture safety means (prevention, protection, intervention) present or applicable in a system. On the other hand, if used indiscriminately in complex systems, the method becomes very difficult to practice. The method is commonly used in the analysis and retrospective explanation for the observed consequences arising from a failure of the system.

The procedure for applying the method - generally applicable approach to achieving risk analysis trough events tree involves the following steps:

\footnotetext{
${ }^{*}$ Corresponding author: radumares50@gmail.com
} 
I. Defining initiator event;

II. Identification the functions safety - preventive;

III. Building the tree;

IV. Analysis and valorization of tree [2].

\section{Case study: Work accident - Mechanical department}

Occupational accident investigation file of worker's temporary work incapacity must contain:
A) identification of work accident
B) accident investigation report
C) spot observation note
D) technical report of bridge crane inspection
E) official report on the technical verification of bridge crane
F) sketch of the accident site
G) pictures from the scene
$\mathrm{H})$ injured declaration
I) witness declaration
J) leader job declaration

We try to identify membership in the four elements of tree events for all elements of the research dossier of work accident.

I) In the mechanical department during the operation of compressed air tube has been a work accident by cutting off the thumb and index the left hand of the worker $\mathrm{X}$ by crane operated by the worker Y. The event was produced at the level of travel path of the crane located at a height of about 4, $5 \mathrm{~m}$ around the time 10,30, in 15012011.

II) Accident investigation report:

a - date of the conclusion of official report: 20012011

$\mathrm{b}$ - names of persons performing accident investigation report: $\mathrm{AB}$ undersigned chief internal service desk OSH inspector MR SSM domestic service, CI Eng. HR, the members of the investigation committee under Decision 1/2011, I researched the event whose victim was working $\mathrm{X}$

$\mathrm{c}$ - time and place where the investigation was conducted, the circumstances and causes which led to the accident occurred during 15012011 - 20012011 and have been carried out at the place of production of the event at the mechanical processing

$\mathrm{d}$ - the object of investigation: was done in order to establish the circumstances and causes that led to the accident, legal regulations violated, responsibilities and necessary measures to be taken to prevent the occurrence of other similar cases and to track the accident

e - date- event time: the event was produced in 15012011 around 10,30

$\mathrm{f}$ - place of the event: event occurred in the mechanical processing department at the rolling track of bridge crane

$\mathrm{g}$ - employer identification data: SC ABC SRL, mechanical processing department

$\mathrm{h}$ - identification data of injured worker: name $\mathrm{X}, 40$ years, romanian citizen, mechanical maintenance, 22 years work experience, seniority at work 20 years

$\mathrm{i}$ - detailed description of the place, equipment, circumstances and manner in which the event occurred: On 15.01.2011, 10:30, Mr. Y - supervisor in the mechanical department announced by phone the workers from prevention and protection service of society, about an event in mechanical department. The event consists in worker X injury at mechanical maintenance department, respectively worker injury by trapping the worker hand between gears from the translational movement of the bridge crane. Investigation commission appointed by decision of the company manager has moved onsite for research in this event by compiling a note on the findings. 
i.1 - detailed description of the place of event: From the statements on the record event occurred on the premises, mechanical department, on the rails of the bridge crane located at a height of about 4.5 meters from the ground. Machined parts within the section is handled from one work station to another by overhead crane operated from the ground by a crane authorized I.S.C.I.R. A team of three workers of the maintenance department works for compressed air network expansion in order to connect to a new chamfered machine. The work is performed near the path of the bridge crane. Within the department the main business is sanding, cutting.

i.2 - In the mechanical department the workers are using the following work equipment: oxy-fuel cutting torch, keys and specific devices plumber profession compressed air installations. In cut marks section is handled from one work station to another by bridge crane operated from the ground by crane authorized I.S.C.I.R. The bridge crane having last check parameters: nominal load $\mathrm{t} S \mathrm{Sn}=5 \times 16.5 \mathrm{~m}$ wide. Last check carried out in accordance with inspection report no. 23-37 / 2011 consisting of technical inspection in use with a maturity of verification until October 31, 2011.

i.3 - detailed description of the circumstances: On 15.01.2011, the mechanical department workers led by RD, prepared the ground pipes were to be fitted to measure welded thread whereon measure valve and pipe insulation necessary for connection to the compressed air network of chamfered machine. Once executed this operation after X and G to climb on the rails to take measure pipe that was to be mounted on top of the rails. At around $10.30 \mathrm{X}$ on its own initiative asked $G$ to climb to access path next to the bridge crane. Arriving at the place for them to connect the chamfered machine measures they have raised the bulb with welding hoses on the crane platform. According to RD supervisor after he left gate valve and fitting to be mounted on pipes attached to the undercarriage of the crane, work that would be carried out during a lunch break at 11:00 when all work equipment in department were to be stopped.

i.4 - detailed description of how the event occurred: At around 10.30 X and G were on the platform next to the crane runway, they took measures of pipe that was to be mounted on top of the path of the crane. Meanwhile in the mechanical department the bridge crane operated by FI (authorized ISCIR, license no. C, carry parts to chamfered. When movement of bridge crane the two workers from the maintenance department were near the rolling track of the crane. From G's statement shows that it was on the 1st line support pole near the runway crane and $\mathrm{X}$ on line 2 . X, according to the statement, the board decided to cut with oxyacetylene burner gas welding being facing the pole on line 2 , at which the bridge crane it was hanging on the padded coat, it twisted and injured by pressure from the bridge crane and the metal structure of the access on his legs and left hand by gearing gears from mechanism translation. The root cause: Making improper commands, maneuver.

j. - Consequences of the event and / or consequences suffered by injured: According to medical conclusions issued by the Arad County Emergency Service, in address nr./.2011 X suffered multiple trauma; crushing injuries left hand with: amputation inter phalangeal, metacarpal joint-phalangeal dg. 2; dorsal contusion wound finger 3; volar soft tissue avulsion $\mathrm{f} 2$ - $\mathrm{f} 3$ finger 4; 3 finger amputation phalanx 5; right ankle fractures; malleolus left fractures

k. - cause of the event: From the above analysis and documents on file, based on the circumstances in which the event occurred as a result the main reason that the victim $\mathrm{X}$ is due to improper command-maneuvers. Improper handling of the bridge crane of a worker's injury X F and I was in the area of the crane runway led to violation of art 22 of Law no 319/2006 occupational safety and health updated: "Every worker must operate in accordance with his training and instruction and instructions of the employer, so as not to expose themselves to risk of injury or occupational disease both self and other persons who may be affected by the actions or omissions during the work "of the provisions of article 2 , 
section. 2.2, chapter II of internal regulation: ,, ... in addition, all employees have a legal obligation to take care of them themselves and any other person who may be affected by their acts or omissions at work, cooperate with the company and all other persons who are directly or indirectly involved in the activities of the company. All working methods should be regularly checked to ensure that it applies the most secure methods possible. ". Also not been complied with regulations PT R1 / 2010 ISCIR, edition 1,, responsibilities crane lifting machines during work of art. 121 lit. a: , - to maneuver only on the orders in accordance with the code signaling load slinger designated; The stop signal them to consider the other person " and lit. s, - to not allow anyone to climb the crane when it is connected to the power supply circuit.". According to official report no 6C 2011, I.S.C.I.R., Oradea city. Code 23 -03 carrying out orders improper maneuvers.

1. - Other causes which competed at the event: 1 . bullish X's own initiative and requested that the $\mathrm{G}$ to climb the access path to tread the crane were exposed and led to violation of art 22 of law no 319/2006 occupational safety and health. updated: "Every worker must operate in accordance with his training and instruction and instructions of the employer, so as not to expose themselves to risk of injury or occupational disease both self and other persons who may be affected by the actions or omissions during the work "; the provisions of article 2, section. 2.2, chapter II of internal regulation: ,... In addition, all employees have a legal obligation to care for themselves and any other person who may be affected by their acts and omissions during work, cooperate with the company and all other persons who are directly or indirectly involved in the company's activities and art. 17 of Instruction own health and safety at work for work at a plumbing and gas, water, heating,, staff worker will perform only works entrusted by the leader of the band for work and only those who are qualified and authorized if it have deactivated all technical equipment that workers can get in touch. "2. When carrying out reconstruction work at the event was found to lack defenders protective gear gears from translational movement of the crane-crane. Were violated GD 1146/2006 Annex 1 art. 2.8.1,, where mobile devices of work equipment risk of accident by mechanical contact, they must be provided with guards and protective devices to prevent access to dangerous areas ..."

m. - other observations during the event investigation: 1. Employer has ensured the organization of prevention and protection unit by setting up a national prevention and protection services in the ministry's coordination. 2. The employer is in possession of a risk assessment of injury for workplace where the event occurred, based on risk assessment being drafted injury prevention and protective plan. 3. Victims event was instructed in terms of safety and health at work last regular training being carried on 03.01.2011. 4 . There is OSH instructions in relation to work. 5. The job descriptions were established duties and responsibilities regard to occupational safety and health of the worker $\mathrm{X}$, corresponding to the performed position.

$\mathrm{n}$. - the persons responsible for violation of legal regulations of chapters from point $\mathrm{K}$

1. - F.I. locksmith for those established in chapter $\mathrm{k}$

2. - X maintenance mechanic and G plumber for those established in chapter L.1

o.- proposals for administrative sanctions and disciplinary: FI is punishable by suspension of crane authorization over a period of three months, $X$ and $G$ is punished with disciplinary warning according to Labor Code 2003 (Law 53/2003) art. 248 lit a.

p. - proposals for penal investigation: this is not the case

q. - character of the accident: according to article 32 paragraph 1 of the law 319/2006 updated with regard to art. 135, paragraph 1 of H.G. 1425/2006 accident suffered by X is recorded as accident with temporary work incapacity

r. - ordered measures to prevent further similar events and those responsible for their implementation: 
1. Processing causes and circumstances of the incident with all working personnel within the company. Deadline: 10 days from the receipt of the investigation report

2. Mounting the protective elements of the gearing gears from translational movement of the bridge crane. Deadline: Immediately.

3. It will review the action in prevention and protection plan and taking into account the causes of the work accident and other circumstances occurring after its preparation as required by art. 46 paragraph lin methodological norms of Law no 319/2006 occupational safety and health updated, approved by H. G. 1425/2006 and amended by H. G. 955 / 2010.Deadline: 10 days of receipt of the investigation

4. Occupational risk assessment will be updated as required by art 15 pt 1 of the methodological norms for the application of Law No 319/2006 occupational safety and health updated, approved by H. G. 1425/2006 and amended by H. G. 955/2010. Deadline: 10 days from the receipt of the investigation report..

s. - Reporting deadline to the Territorial Labor Inspectorate regard the implementation of the measures referred to in subparagraph s: Territorial Labor Inspectorate will be informed in writing regard the implementation of measures ordered within 15 days of the approval of investigation dossier.

t. - The number of copies that ended official report and their distribution: This official report ended in quadruplicate and submitted as follows:

- a copy for the company

- a copy to the Territorial Labor Inspectorate

- a copy to the County Pension

- a copy to the victim $X$

u. - employer stamp

III) Representation of events tree for maintenance operation:

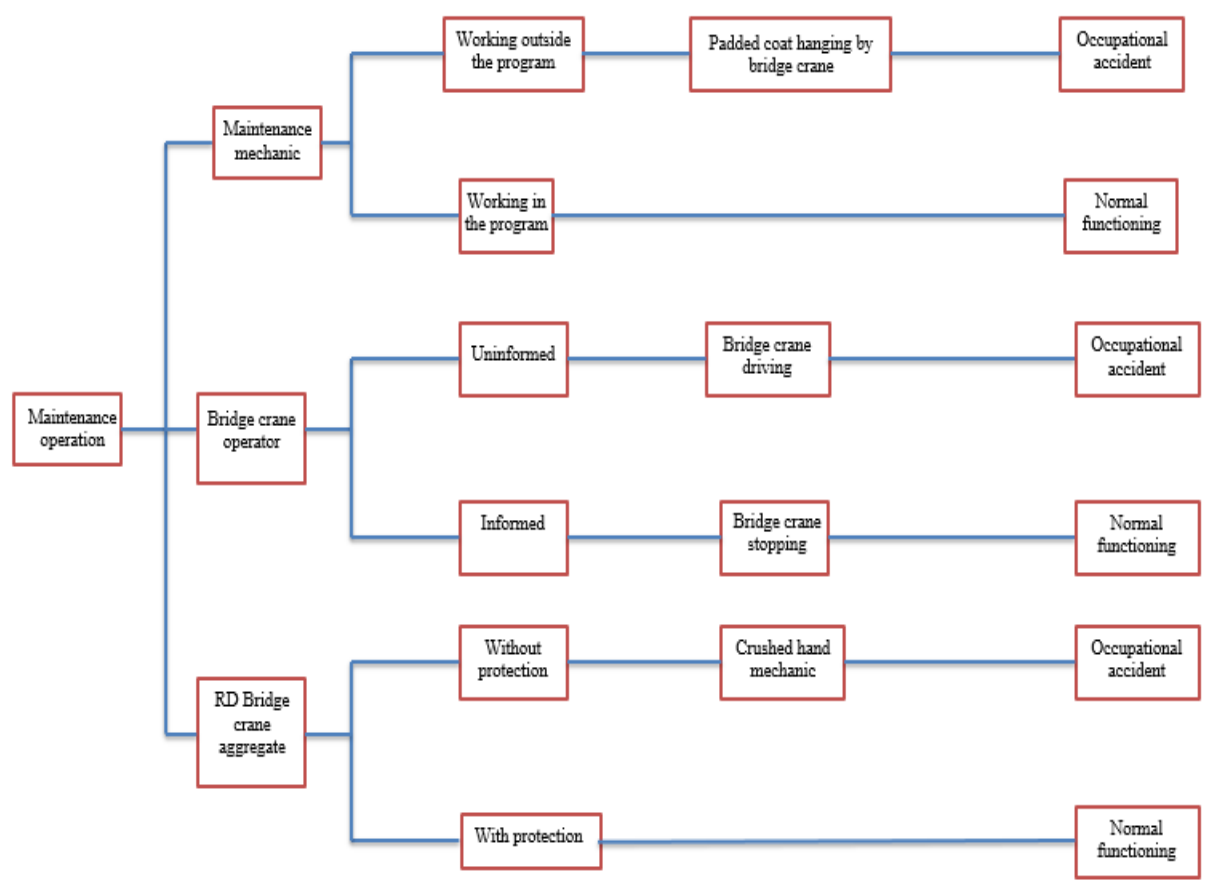

Fig.1. Events tree 
IV) Analysis and exploitation of tree:

- If during the maintenance operation worker $\mathrm{X}$ will carry out activity during the program and will inform the crane bridge operator on the fact that he operates on the runway, then the whole system will operate normally;

- If during the maintenance operation worker X will carry out the activity outside the program and will not inform the bridge crane operator that he is at work will result a work accident;

- If during the execution of maintenance operation the worker X will be hanging from the bridge crane and it will have R D covered with a shell, then the probability of having an work accident and catching worker $\mathrm{X}$ hand between $\mathrm{R} \mathrm{D}$ and the system will operate normally;

- If during the execution of maintenance operation the worker $\mathrm{X}$ will be hanging from the bridge crane and it will not have R D covered with a shell, then the probability of having a work accident and catching workers hand between $\mathrm{R} \mathrm{D}$ and will result in a work accident.

\section{Conclusions}

Event Tree Analysis method of a work accident is a quick and efficient method that allows starting from an initiator event and browsing systemic causes of the accident to establish the sequence of events. What articles of the legislation, the specific regulations and internal rules, were not complied. To establish technical and organizational measures necessary to prevent further accidents. The method also allows establishing relations with enough finesse to determine: cause - effect.

\section{References}

1. Moraru R.I., Securitate si sănătate în muncă: tratat univeristar, (Editura Focus, Petrosani, 2013)

2. Moraru, R. I., Băbuț, G. B., Cioca, L. I., Environmental Engineering and Management Journal, 13 (6), 1371-1376 (2014)

3. Torretta, V., Rada, E. C., Ragazzi, M., Trulli, E., Istrate, I. A., Cioca, L. I., Waste Management, 45 (SI), 152-160 (2015)

4. Cioca L. I, Moraru R. I., Archives of Mining Sciences, 57 (1), 53-60 (2012)

5. Ivaşcu, L., Cioca, L. I., The $2^{\text {nd }}$ International Conference on Psychology, Management and Social Science, Psychology, Management and Social Science, Shenzhen, China, Book Series: Advances in Education Research, 49, 77-80 (2014)

6. Cioca, L.I., Moraru, R.I., Băbuț, G.B., Proceedings of the $15^{\text {th }}$ International Scientific Conference „The Knowledge Based Organization”, 2, section: Management, 43-48, Land Forces Academy Sibiu (2009)

7. Legea nr. 319/2006 a securității și sănătății în muncă

8. Hotararea de Guvern $1425 / 2006$. HG pentru aprobarea Normelor metodologice de aplicare a prevederilor Legii securitatii si sanatatii in munca nr. 319 din 2006 